\author{
Una Popović \\ University of Novi Sad, Faculty of Philosophy, Dr Zorana Đinđića 2, RS-21000 Novi Sad \\ unapopovic@ff.uns.ac.rs
}

\title{
Aesthetics of Nature in Contemporary Context
}

\begin{abstract}
Aesthetic of nature is in this paper presented in the context of its revival in contemporary philosophy. Nature as the object of aesthetic experience and valorisation is mainly a question of traditional aesthetics, so its revival is here presented as the problem of redefinition of aesthetics in contemporary terms. The analysis encompasses examples from contemporary aesthetics, philosophy and art, and it is focused on revealing the key features of new aesthetic understanding of nature. These key features are in conclusion seen as indications of the future perspective of the development of philosophical aesthetics.
\end{abstract}

\section{Keywords}

aesthetic of nature, nature, aesthetic experience, art, work of art, contemporary philosophy

Throughout the history of aesthetics, the problem of nature represented one of the most important problems for aestheticians. Since the ancient beginnings of philosophical considerations of the aesthetic domain, nature was in the centre of these theoretical efforts. Although antiquity does not recognise aesthetics as a separate field of philosophy, and although it differentiates the theory of beauty and theory of art, one can concur that it was exactly the question of aesthetic aspect of nature that had prominent role in these considerations and that therefore the nature is here seen as the main aesthetical phenomenon. As such, the aesthetic experience of nature had a role of the fundamental ground on which more universal aesthetical theories would further be developed, which are to be relevant for both natural and non-natural, artistic objects.

For example, if we are to investigate the role of nature in the context of the ancient theory of arts, Plato's influential theory of imitation (mimesis) would be a good starting point. In the "X" book of Republic Plato argues against visual arts and, in consequence, against arts as such on the grounds of their mimetic character. ${ }^{1}$ Although Plato does not explicitly compare natural and artificial objects in aesthetic respect, he does imply that the object which would be one step closer to the ideas than an artistic one would not be subject of his scorn. Such object, in the context of the argumentation from the " $\mathrm{X}$ " book of Republic, would also be artificial, but not an artistic object: the example he presents us with is a bed, made by a craftsman, which is different from its representation given by a painter. On the other hand, as a candidate for such an

Myles F. Burneyeat, "Art and Mimesis in Plato's Republic", in: Alison E. Denham (ed.), Plato on Art and Beauty, Palgrave MacMilan,
New York 2012, pp. 54-71, pp. 58-59, doi: https://doi.org/10.1057/9780230368187_3. 
object, one could also consider natural objects, given that they are not products of artistic mimesis and that they, according to the "IV" book of Republic, metaphysically belong to the same domain as the previously mentioned bed. ${ }^{2}$ Therefore, natural objects - even the ones we could mark as aesthetically pleasing - would in Plato's philosophy be excluded from his critique given in the " $X$ " book. If we bear in mind the immense influence of Plato's theory on the further development of aesthetics, we can trace this idea in the later prominent status of aesthetics of nature.

A similar way of thinking is to be found in the context of ancient theories of beauty. Here also one can see the prominent role of nature in the domain of aesthetics: natural objects were considered as the primary objects of beauty, and the constitution of beautiful natural objects was taken as the model for universal determination of beauty as such. For example, the great theory of beauty, as Tatarkiewicz calls it, defines beauty in the context of relations between the parts and the whole, which are to be harmonic and symmetric. ${ }^{3}$ Such definition of beauty derives from natural objects and imitates their organic constitution: to be beautiful, artistic objects should - given such condition of beauty - be made as if they are natural, organic objects. An interesting example that proves our point can be found in Aristotle's Poetics, where Aristotle even determines the essence of the arts - techne - as an imitation of nature in a positive context. ${ }^{4} \mathrm{He}$ even comments on the very structure of the tragedy in terms of the organic constitution of animals. ${ }^{5}$

However, such prominent status of nature in aesthetics was inverted after Kant. More precisely, in philosophies of Schelling and Hegel, which were followed by many others, it is art that dominates the domain of aesthetics, and nature is either completely banned from aesthetics, as with Hegel, or degraded to the aesthetic phenomenon of second-rate status, as with Schelling. Such decline of aesthetic of nature is further reinforced by the new artistic practices in contemporary times, which posed various complicated and ground-breaking questions to the aesthetics so that in the 20th century one can hardly find traces of its traditional prominent position.

There are exceptions, however. During past several decades, starting from the sixties, one can see the revival of aesthetics of nature in various domains of aesthetics. This revival is, of course, realised in a completely different context than the earlier fundamental positioning of aesthetic of nature, but it nevertheless is a revival, and therefore it represents a statement of a new shift in aesthetics, i.e. in the way in which contemporary aesthetics operates. The intent of this essay is, therefore, to present the aesthetics of nature in its current, contemporary status.

\section{Nature is Art}

One of the most important differences between the status of arts and nature in traditional and contemporary aesthetics is exactly the question of their differentiation: whatever constituted their character in various aesthetics of western tradition, in whichever manner arts and nature were conceived, they always represented two separate, even metaphysically different domains of aesthetic phenomena. We already mentioned that the domain of nature had the prominent position in the traditional context, and this was exactly due to its metaphysical supremacy over the realm of arts; once metaphysics was rejected as the perspective that governs aesthetical analysis, nature also failed to fulfil its previous role. 
However, in contemporary aesthetics, with its revival of nature as an aesthetic phenomenon, such differentiation is not to be found - at least not in the way in which it constituted traditional aesthetics. Revival of aesthetics of nature in contemporary philosophy does not imply that it is restored to its previous, traditional primary position, but quite the opposite - it implies that the nature as aesthetic phenomenon now can only be seen mediately, in terms of something else. To put it more simply; the aesthetic character of nature is not, as such, immediately given any more - for a contemporary observer nature is not the primary object of aesthetic experience, not the primary object of beauty or any other aesthetic value. Nature lost its aesthetic status and presence for us due to the new view on nature, mediated through science and technology, which in turn presents nature as the domain of scientific investigation and resources. ${ }^{6}$ Therefore, its aesthetic presence, if it is to be experienced at all, has to be mediated; it demands almost artificial, non-natural stance and observation.

To conclude; the new, contemporary view on nature as an aesthetic phenomenon presents us with an equally new phenomenon of nature, both in terms of nature as such and in terms of its aesthetic character. Aesthetic character of nature, to put it differently, is not the same aesthetic character of nature that dominated traditional aesthetics; nature, as seen from contemporary perspective, is not the same nature as it once was. The main difference in this respect is, as we already suggested, merging of the two previously strictly separated aesthetic domains - art and nature. ${ }^{7}$ Not only that nature, to be aesthetic once again, has to be seen in terms of something else - in this case predominantly in terms of art, but due to that it also becomes something else than it once was. If nature is to recover its aesthetic character, it now has to become art, or at least to become artistic.

Such a shift in the treatment of nature, however, also signifies some interesting changes in contemporary understanding of art as such. Namely, the previously mentioned difference between art and nature was one of the main guidelines in the development of new artistic practices that dominated the arts since the end of the 19th century. Non-representational, non-figurative and non-objective, abstract art movements all insist on the liberation of art from the realm of natural, objective reality as its model and criterion. These art movements all put critical distance from the above-mentioned theory that art should be mimetic, that it should imitate, and especially that it should imitate nature and natural objects. At the same time, they proclaim new freedom of art, both given the subjects they artistically present and in view of the manner of their presentation; from then onward, art is free to present and is not

2

Stanley Rosen, Plato's Republic. A Study, Yale University Press, New Haven - London 2005, pp. 263-264.

3

Wladyslaw Tatarkiewicz, A History of Six Ideas. An Essay in Aesthetics, Martinus Nijhof, The Hague - Boston - London 1980, pp. 125-129.

4

Martha Husain, Ontology and the Art of Tragedy. An Approach to the Aristotle's Poetics, State University of New York Press, New York 2002, p. 22
5

Aristotle, Poetics, translated by Joe Sachs, Focus Publishing, Newburyport (MA) 2006, p. 30 (1450b-1451a).

6

Glenn Parsons, Aesthetics and Nature, Continuum Publishing, London - New York 2008, pp. 2-3.

Malcom Budd, "The Aesthetic Appreciation of Nature as Nature", The Aesthetic Appreciation of Nature. Essays on the Aesthetics of Nature, Clarendon Press, Oxford - New York 2002, pp. 2-7. 
obligated to re-present. Distance of art from nature has, therefore, gained the same prominent position that was earlier occupied by their essential relationship, seen as the relationship of mimesis.

However, some contemporary art practices and movements give sway to a new interpretation of such distance between art and nature, and of the freedom of art from nature. Instead of full escape from natural reality as their criterion and model, such art movements inverse the process and now allow nature to step into their field, to step further into the art itself, all the while remaining critical towards the theory of mimesis. A sparkling example of such art movements is so-called Land Art, i.e. Earth Art. This art movement came to be in the USA in the late sixties, as a protest against the artificiality and commercialisation of art, but its significance in the context of aesthetic and the proclaimed relationship between nature and art is much more important for our present purposes.

Namely, Land Art artists abandoned museums and galleries and went out of the cities, to nature itself. This was the first and the most explicit aspect of their protest and intent: by doing that, they proclaimed that art is not to be obligated to urban and social context, with all its problems, but has universal meaning and purpose. Art is not something to be encapsulated into the social domain and is not to be a mere reflection of problems and tensions of society. Of course, stepping one step back from the urban and social domain is not enough to be completely out of it; this can only deliver a necessary distance between the artist and society that is also a kind of social construct which serves as means for the critique of society. However, Land Art artist are aware of such consequences, and they accept them, sometimes even reflecting upon them. As Alan Sonfist, one of the pioneers of the Land Art movement puts it:

"Public monuments traditionally have celebrated events in human history - acts of heroism important to human community. Increasingly, as we come to understand our dependence on nature, the concept of community expands to include non-human elements."

However, such a critique of social problems, and especially of the role of art in society, was not the main interest of these artists. By stepping into nature and out of galleries, they did not only refract and reflect art and society in their interconnections, but they also gave a new impulse to understanding of art. For their work they used natural materials, such as wood, stone, water, plants, sometimes mixing them with artificial materials, such as metal or concrete. This procedure also does not bear a mark of something new; artists in their work always made use of at least some of those materials. The main difference here is not to be found in materials that artists use, which are natural or more natural than it was usual, but in the way they made use of them. ${ }^{9}$

Namely, Land Art artists made large work of arts which can only proximately be called sculptures. They intervened in nature as such, that is in the landscape, which in turn became the work of art. Therefore, Land Art proclaims that the art is to be realised not only using natural materials and objects, not only within the natural surroundings but in nature itself and as nature. ${ }^{10} \mathrm{Or}$, to put it the other way around, they proclaim that nature is - or can be - art.

There are several interesting consequences of such art practice. The first and most important one is the very connection between art and nature. Namely, Land Art artists pose a question on the very nature of art as such, and their reply is not - as one could expect - the proclamation of freedom of art in respect to nature, but just the opposite, their necessary connection. ${ }^{11}$ Of course, this interconnectedness of art and nature is quite special, and so is how here nature once again steps into the realm of aesthetic. 
As we have already seen, the use of natural - and non-natural - materials here is not a differentia specifica of Land Art; further, we could say that these materials are just second-rate elements of these artworks. If we are to be precise, we have to say that the landscape itself now becomes material for art: specific natural materials, like wood or water, are seen only as parts of the bigger whole, and have no meaning or use apart from it. ${ }^{12}$ Therefore, Land Art artists intervene not only in nature, but on nature itself, and they create natural-artistic forms and objects that cannot be separated from the rest of the natural surroundings in which they are placed.

This kind of practice is directly opposed to the one based upon the theory of mimesis. Namely, if we are to imitate nature, we do not intervene on it; we use some sort of mediation that is to become a work of art, separate and different from nature. For example, if we are painters, we will have a canvas on which we will apply colours in some fashion and order; we can even bring our canvas into nature and place it there, but still, there will be a canvas - as a mediator - between the artist and nature. To give another example: if we are sculptors, we can put our sculpture in some natural surrounding and consider this practice as a kind of aestheticisation of nature. But, the works of Land Art are different - they do not aestheticise nature, they are nature - and, perhaps, natural. Their works are not sculptures put in nature; they are sculptures made from nature; they do not pose any mediator between artist and nature. There is not any mediating canvas - the nature itself becomes the canvas. It is as if the artists tore the canvas apart and reached directly to the very same object they were supposed to imitate. The freedom of art, therefore, now applies not only to art but also to nature.

Use of natural materials, here seen as parts of the landscape, burdens Land Art works with another interesting feature. Namely, being made out of natural materials, these works of art are subjected to elements, and so they are eroded, they change, and they are essentially mutable. ${ }^{13}$ These are not works of art that are intended to last and endure - they do not have to satisfy traditional demands for eternal value such as beauty. At the same time, they also cannot be interpreted as the 'works of their time' in Hegelian manner, as works that reflect social changes and problems, because they are not intended to be witnesses of the social domain. Works of Land Art are posing a very interesting and at the same time very unpretentious relationship towards the problem of time - they reflect it in the same manner nature does.

The example of Land Art enables us to reflect upon the status of nature in recent art and aesthetics. As we have seen, Land Art gives rise to a new understanding of art itself, making the interconnection between art and nature.

Alan Sonfist, "Natural Phenomena as Public Monuments", in: Kristine Stiles, Peter Selz (eds.), Theories and Documents of Contemporary Art: A Sourcebook of Artists Writings, University of California Press, Berkley - Los Angeles - London 2012, p. 624.

9

Ann Raynolds, Robert Smithson. Learning from New Jersey and Elsewhere, MIT Press, Massachusetts 2003, pp. 82-83.

10

G. Parsons, Aesthetics and Nature, pp. 128-

129.
11

Allen Carson, Aesthetics and the Environment. The Appreciation of Nature, Art and Architecture, Routledge, London - New York 2000, p. 151 .

12

G. Parsons, Aesthetics and Nature, p. 129.

13

Arnold Berleant, The Aesthetics of Environment, Temple University Press, Philadelphia 1992, pp. 111-112. 
However, at the same time, Land Art aesthetically reflects not only art but also nature: it presents nature as an integral part of the art. ${ }^{14}$ Nature, therefore, here becomes art, and only as art has aesthetic relevance. That is: although there are no more mediators between artist and nature, although this mediation is cancelled, the same act that cancels mediation in the realm of creation of art introduces mediation in the realm of its reception, introduces meditation between spectator and nature.

Land Art works present nature to their recipient through the perspective of art, and by doing so, they reveal the aesthetic character of nature in a completely new manner. Nature as an aesthetic phenomenon is now liberated, it can once again be seen and perceived, but to be part of the aesthetic experience, it must show itself through - or as - the artwork. Nature is, therefore, once again seen as the aesthetic object, but as such it has to be revealed - no more can it be immediately perceived as beautiful, sublime or aesthetic at all. Its aesthetic character is here not cancelled, but just the opposite - it is heavily accentuated, given that landscape and nature are the medium of artist's work, and that the forms that they make are also very natural, fitted into untouched natural surroundings. In such context art as such gains a new role: it should reveal the aesthetic status of nature, it presents us with new optics related to nature. ${ }^{15}$

The aesthetic character of nature, therefore, is once again regained. It should be noted that it is regained artistically, that is that nature as aesthetic has to be revealed by some non-natural practice, with the help of something different from nature. Also, it should be noted that the example of Land Art can serve as a sign of change in the aesthetic treatment of nature: if nature as aesthetically relevant can only be seen mediately, then we can ask ourselves what does this new view on nature exactly reveals?

\section{New Nature: Aesthetics and Science}

During the 20th century philosophy as such forged itself mostly through a dialogue with contemporary science and in view of its impact on human society and environment. Philosophers like Heidegger, Adorno and Fedorov drew our attention to devastating consequences of science and instrumental world-view, advocating for a different way of thinking, more adequate to the character and needs of human society. Such remarks gained sway over time, finding their place in aesthetics: contemporary aesthetics is often seen as an alternative to science, especially in the context of nature.

For a contemporary human being nature cannot be seen as natural surrounding anymore. The world we live in is urban, social world, deeply immersed in our daily affairs: going out into nature is now merely an exception, a kind of distance from the ordinary, a picnic. Moreover, nature is now mostly urbanised, and one can rarely find such a landscape that is not intervened with electrical power cables. Finally, nature as the object of aesthetic experience and delight is closer to us in the form of HD video programmes, such as Animal Planet, than in its primary state; i.e. it is mostly presented to us through the mediation of technology.

These considerations can now present a brief sketch of explanation concerning the new, mediate view on aesthetic character of nature. If nature as such is now refracted for the observers, in such a manner that they approach it out of social or culture paradigm, then it also must be refracted or mediated in aesthetic experience. However, the problem here is one of greater importance: contemporary philosophers often imply that the aesthetic character of nature 
cannot be seen at all exactly due to this scientific and technological worldview. This would, in consequence, imply that the aesthetic character of nature as such is a 'natural' feature of nature - which is, obviously, a step back to the traditional conceptions.

Therefore, the new aesthetic experience of nature, mediated through art, is not only the result of critique of contemporary imperative of technology and science, but also an interesting implicit comment on aesthetic character of nature as such, given in new terms, affecting not only our aesthetic understanding of nature, but also our concepts of perception and experience. That is to say, this new view on nature presents us with an equally new understanding of nature as one of the objects of our experience, and with a new understanding of the experience as such. Such considerations have found their way in contemporary aesthetic theories, giving rise to yet another almost forgotten domain of aesthetic inquiry - the problem of aesthetic experience.

The aesthetic experience was given a prominent role in aesthetic for the first time in the first aesthetics of them all - namely, in the philosophy of Alexander Baumgarten. He founded aesthetics as a separate field of philosophy, proclaiming aesthetic experience as the very foundation on which one can develop a coherent theory that would embrace both theory of arts and theory of beauty. However, although his project of aesthetics as a comprehensive study of aesthetic experience, arts and beauty lived on, and remained a kind of burden for every future philosophical aesthetics, his solution to accentuate aesthetic experience did not have many followers. Nonetheless, in view of our previous considerations concerning the new aesthetic character of nature, it seems that contemporary aesthetics is once again pulled in this direction.

An example can be found in the philosophy of Arnold Berleant. He advocates the rethinking of the whole domain of experience and perception, criticising the modern subject/object gap and insisting on a new form of its understanding. Concerning the experience of art, for example, he says:

"The experience of art involves not so much the transmittal of experience from artist to observer as a sharing among people and objects that participate in an aesthetic situation."16

The experience of art, therefore, is not seen as the linear process that occurs between an artist/subject, a work of art/object and an observer/subject, but as a complex interconnection of various factors forming a kind of web - an aesthetic field of experience. This kind of explanation of aesthetic experience equally includes production and reception of art, as well as its objectified instance (work of art) and the social domain of its possible meanings and functions. In other words, Berleant's theory of the aesthetic experience of art is all-embracing: it is open to all perspectives that can be seen as constitutive of such experience in any given instance.

Such theory of the aesthetic experience of art is, however, even more embracing, given that Berleant is not willing to restrict it to the field of art alone: the structure and understanding of art experience are in his philosophy valid for the experience of nature as well. More precisely, it presents us with a valid model of experience as such. In Berleant's philosophy, there is no structur-

14

A. Carson, Aesthetics and the Environment, pp. $155-156$.

15

Ibid., p. 157.
16

Arnold Berleant, "The Aesthetic Field: A Phenomenology of Aesthetic Experience", Leonardo 6 (1973) 2, p. 190, doi: https://doi. org/10.2307/1572722. 
ally 'higher' or more valuable experience, that would, in turn, serve as the correct model on which other variations of experience could be reduced; any experience is, according to Berleant, constituted as a field of experience, as an interconnection that operates dynamically. Therefore, he says:

"The physical senses play an active part, not as passive channels for receiving data from external stimuli but as an integrated sensorium, which equally accepts and shapes sense qualities as part of the matrix of perceptual awareness." 17

Berleant's theory of experience, therefore, allows for various modes of experience to converge to one complex system, leaving aside the differences in context that traditionally dominated their understanding. For example, the theory of art experience is now easy to connect with the theory of the aesthetic experience of nature, not because there is common aesthetic ground between them, but because there is a common experiential structure which does not exclude one from the other. In this respect, he even uses the results from an investigation of one mode of experience - for example, the experience of art, to the benefits of consideration of another mode of experience - for example, education. ${ }^{18}$

If we are now to give an account concerning the aesthetic experience of nature in its new, contemporary form, we can conclude that in Berleant's philosophy nature is revealed as the environment. More precisely, the concept of environment is here seen as the counterpart of the field of experience mentioned above, and nature is accentuated as its primary model, although it also encompasses art, as well as "the city as much as the countryside". ${ }^{9}$ As Berleant puts it:

"The experience of nature is not an occasion enclosed by boundaries that protect it from the irrelevant incursions of the surrounding world. Like art, the aesthetics of nature holds great importance for the quality of experience in general. It displays the richness of the ordinary, the small, the local. It unfolds the values that reside in solitary times out of doors. It recognises the sense of community in sharing those times with others." 20

In other words, the experience of nature is, although primarily orientated on nature, at the same time experience that involves spectator and society. Moreover, such experience of nature, in its primary form, is and should be the subject of aesthetics.

Therefore, as the subject of aesthetics, nature is here revealed not in its traditional form - as the beautiful natural object, or as the sum of such objects - but in a new and rich sense. In other words, nature is here seen as the subject of aesthetic inquiry not because it is beautiful, sublime etc., but because it presents us with a broad experiential field that in turn reveals the very structure of our own experience.

The same could be said of art or experience adequate to social relationships, but in comparison to them, the experience of nature has for Berleant at least two theoretical advantages. Firstly, it cannot be reduced to the one-on-one model of experience, to the subject/subject model (even if mediated through some artificial object); it, therefore, demands rethinking of both traditional subject/object and more contemporary, communicational subject/subject experience models. Secondly, the experience of nature is traditionally seen as an ordinary experience, juxtaposed to 'special', aesthetic experience, predominantly one concerned with arts. By accentuating the experience of nature Berleant wants to cancel this differentiation, i.e. he calls for a broader sense of aesthetic experience - such a sense that would reveal possible aesthetic 'content' in every kind of human experience, even in the ordinary human 
environment. ${ }^{21}$ In turn, the experience of nature is now seen as always and in advance mediated, while we are its integral part as much as we are an integral part of experiences characteristic for the social domain. And this would be concluding understanding of the provocative and extravagant aesthetic character of nature in traditional philosophy: nature can be experienced as beautiful, sublime etc. not because it objectively has those features, but because it is open for us to experience it at all. Berleant says:

"For the mutual influence of perceiver and object that is a central element in aesthetic experience eloquently expresses the general pattern of all experience. The arts do not only interpret our world; they serve as an exemplar of ways in which we participate in constructing it."22

The same could be said for nature: our (aesthetic) experience of nature is not merely passive subjection to some outward inputs, but active and engaged construction of our world. Given this, there could indeed be new aesthetics of nature, such that could pass over the disciplinary differences of tradition and pose aesthetic experience - as well as its corresponding aesthetic object (of any kind) - as a new integral concept, one that could stand as a basis for new aesthetics. Berleant calls this the naturalisation of aesthetics

“... [by moving toward] its association and continuity with other regions of experience, and toward identifying the aesthetic as a critical dimension of the value that binds together the many domains of the human world." 23

\section{Perspectives for an Aesthetic of Nature}

The problem of nature in contemporary aesthetics - as well as in contemporary art - is, as we have already seen, one of many perspectives and complex structure. Enough was said concerning the differences between the traditional aesthetic status of nature and the contemporary one: nature lost its primary position, it lost its metaphysically guaranteed stature, it lost its role of the prominent aesthetic phenomenon and, most importantly, it lost the very immediacy of its givenness. In the contemporary context, nature is something lost, something not within the immediate grasp, something different - one could even say that nature became the very principle of difference. In such a context, if there is to be any aesthetics of nature once again, it has to be regained anew, it has to be proven as possible and necessary.

However, it would be wrong to expect this new aesthetics of nature to be one separate philosophical discipline among others, to be realised in opposition to other domains of aesthetical or philosophical research. The tendencies of contemporary philosophy and art are not in convergence with such an idea; on the contrary, interdisciplinarity and mutual cooperation between the fields of sci-

17

A. Berleant, The Aesthetics of Environment, pp. 14-15.

18

Arnold Berleant, "Education as Aesthetic Process", The Journal of Aesthetic Education 5 (1971) 3, pp. 139-147.

19

Arnold Berleant, The Aesthetics of Environment, p. 15

20

Ibid., p. 38.
21

Ibid., p. 59.

22

Arnold Berleant, "Naturalism and Aesthetic Experience", The Journal of Speculative Philosophy 9 (1995) 3, pp. 237-240, p. 238.

23

A. Berleant, The Aesthetics of Environment, p. 161. 
ence and philosophy is the mark of our time. Therefore, one could expect this new aesthetics of nature, if there is to be one, to emerge within these complex interconnections and to bear their character. As we have already seen, this is exactly the case: the domain of aesthetic of nature is once again of interest for philosophy due to its interesting role as crossroads for various important problems, not necessarily of a strictly aesthetic kind. At the same time, this crossroads role is presented as a kind of new pathway for philosophy, while it presents its old subject - nature - in a new manner.

Moreover, it is very important to note that this role of aesthetic of nature in contemporary philosophy grounds itself not in its subject, the nature as such, but in the lack of such subject - in the constant fleeing of nature as such, which is a consequence of contemporary worldview and contemporary way of life. This absent domain, nature, at the same time seems like the present one; nature is all around us, but if one reaches out for it, there is nothing to be found except for urban, human and social horizon. Nature is, therefore, a kind of treasure lost: it has to be found and revealed; it is not ready at hand. Therefore, as we have seen, if one is to find and reveal nature once again in aesthetic terms, one has to deal with the possibilities and character of their relationship towards nature. In consequence, not merely nature, but the aesthetic experience of nature for contemporary thought becomes the main field of interest within this context. If one is to find nature once again, one primarily has to rethink how nature can be approached. The result is not some divination of nature or its aestheticisation, but acceptance of the previously neglected fact that for us there is no nature without us inscribed in it, inscribed in our appreciation of it - the fact that is most vividly revealed in the aesthetic experience of nature.

There are, of course, some exceptions. The very concept of nature and natural was severely criticised during the 20th century and is now mostly abandoned as legitimate in various ethical and political contexts. Thus, one can also ask is there something as nature at all, or is this concept misleading in all its connotations? If it is so, there is a wide spectrum of new possibilities opened, possibilities that would surely challenge our concept of aesthetics as well.

Examples could easily be found in posthumanism and transhumanism. Artists, as well as scholars that share post- and transhumanistic ideas are more than willing not only to abandon and change nature but to intervene into human (physical) nature as well. Posthumanist works of art often present us with new kinds of experience, one that 'normal' human beings would not be able to have, as in work of Stelarc for example. ${ }^{24}$

An even more striking example here would be bioaesthetics, as presented in works of Eduardo Kac, an artist who combined scientific and artistic approach to creation, entering the laboratory and inventing completely new natural beings. ${ }^{25}$ The question here, of course, is whether these beings are natural at all, given that they are not a result of natural processes, but artistic and scientific practices. However, one must notice that this is not merely a scientific question, while Kac is not a scientist, but an artist. Although his works can and will be interesting for bioethics or philosophy of science, they are presented as works of art, and therefore they have implications on aesthetics.

One could argue that Kac wanted to present us with new possibilities of aesthetic experience, the likes of which were never seen before. Although humanity already faced itself with cloned animals and with plant hybrids, never before were they presented as works of art or as objects that should be aesthetically appreciated. It seems that Kac advocated for exactly such perspec- 
tive: his Edunia or his green-glowing bunny should be seen as objects/beings of some aesthetical value. ${ }^{26}$ The fact that we do not have adequate concepts to describe this imposed aesthetic experience is not an argument against it; such works of art are completely new, original, so they are to be incomprehensible, at least at the first instance of our contact with them.

However, the problem runs more deeply than this: the main problem here is that Kac presents us with objects/beings, with proclaimed works of art which will not - at least immediately - give rise to any aesthetic experience at all. Still, he imposes them on us as the objects of such an experience. In other words, it seems as Kac wants to redefine the very concept and understanding of aesthetic experience by presenting us with objects that would usually not be experienced aesthetically and at the same time demanding that they should be experienced in such a way. Finally, by presenting a flower or an animal as a work of art Kac challenges the boundaries between nature and art in a similar way in which Land art artists did.

To conclude: it seems that the revival of interest for the nature in aesthetical respect is to be understood as a vital feature of contemporary and future aesthetics. As we have seen, this revival does not exclude the problems of arts or aesthetic experience, but quite the opposite - it is implied by them. Similarly, although it is primarily intended on aesthetics, this revival implies a broad spectrum of questions that involve cooperation between various fields of philosophy and science. Its revival, as we have seen, goes against the traditional aesthetics of nature and opens new horizons.

Bearing all this in mind, we can conclude by questioning ourselves - is this new aesthetic view on nature the aesthetic experience of nature as such? Was its traditional understanding merely an understanding, deprived of the actual experience? Was the traditional aesthetic experience of nature merely a theoretically governed experience, cultivated view on nature that expected beauty and sublime of it in advance? And finally, is the contemporary perspective on the aesthetical character of nature fundamentally different in this respect?

\title{
Una Popović
}

\section{Estetika prirode u suvremenom kontekstu}

\begin{abstract}
Sažetak
U ovom radu estetika prirode predstavlja se u kontekstu njena oživljavanja u suvremenoj filozofiji. Priroda kao objekt estetskog iskustva i vrednovanja uglavnom je pitanje tradicionalne estetike i stoga je njeno oživljavanje u radu prikazano kao problem redefiniranja estetike u suvremenim terminima. Analiza se sastoji od primjera iz suvremene estetike, filozofije i umjetnosti, i usmjerena na otkrivanje ključnih svojstava novog estetičkog razumijevanja prirode. Ta ključna svojstva u zaključku su viđena kao indikacije buduće perspektive u razvoju filozofijske estetike.
\end{abstract}

Ključne riječi

estetika prirode, priroda, estetičko iskustvo, umjetnost, umjetničko djelo, suvremena filozofija

24

See: http://stelarc.org/?catID=20227 (accessed on February 19, 2017).

25

See: http://www.ekac.org/gfpbunny.html\#gfp bunnyanchor (accessed on February 19, 2017).
26

See: http://www.ekac.org/nat.hist.enig.html (accessed on February 19, 2017). 


\section{Una Popović}

\section{Ästhetik der Natur im zeitgenössischen Kontext}

\section{Zusammenfassung}

In dieser Arbeit wird die Ästhetik der Natur im Kontext ihrer Wiederbelebung in der zeitgenössischen Philosophie präsentiert. Die Natur als Objekt ästhetischer Erfahrung und Bewertung ist hauptsächlich eine Frage der traditionellen Ästhetik, daher wird ihre Wiederbelebung in dieser Arbeit als ein Problem der Neudefinierung der Ästhetik in zeitgenössischen Termini dargestellt. Die Analyse besteht aus Beispielen aus der zeitgenössischen Ästhetik, Philosophie und Kunst und zielt darauf ab, Schlüsselmerkmale eines neuen ästhetischen Naturverständnisses zu entdecken. Diese Schlüsselmerkmale werden in der Schlussfolgerung als Indikationen zu der zukünftigen Perspektive in der Entwicklung der philosophischen Ästhetik gesehen.

\section{Schlüsselwörter}

Ästhetik der Natur, Natur, ästhetische Erfahrung, Kunst, Kunstwerk, zeitgenössische Philosophie

\section{Una Popović}

\section{L'esthétique de la nature au sein du contexte contemporain}

\section{Résume}

Dans cet article, l'esthétique de la nature est présentée dans le contexte de sa résurgence au sein de la philosophie contemporaine. La question de la nature, en tant qu'objet d'expérience esthétique et de valorisation, relève principalement d'une question qui appartient à la l'esthétique traditionnelle. Pour cette raison, sa résurgence est présentée dans ce travail comme un problème pour redéfinir l'esthétique en termes contemporains. L'analyse comprend des exemples issus de l'esthétique contemporaine, de la philosophie et de l'art, et se concentre sur la découverte des propriétés clés pour une nouvelle compréhension esthétique de la nature. En conclusion, ces propriétés clés sont considérées comme des indications pour les futures perspectives qui se rapportent au développement de la philosophie esthétique.

\section{Mots-clés}

esthétique de la nature, nature, expérience esthétique, art, œuvre d'art, philosophie contemporaine 